\title{
Post-Thaw Suspension of Red Cells Cryopreserved with Hydroxyethyl Starch ${ }^{1}$
}

\author{
E. D. ALLEN, L. WEATHERBEE, AND P. A. PERMOAD \\ Medical Research, Veterans Administration Hospital and University of Michigan \\ Medical Center, Ann Arbor, Michigan 48105
}

Post-thaw testing of large units of red cells frozon with $14 \%$ hydroxyethyl starch (HES) indicates $97-98 \%$ of the cells are recovered and about $85 \%$ are stable in saline (1). The quantity of supernatant hemoglobin present in such units at thaw is generally near $450-550 \mathrm{mg} \%$. We have been unable to obtain consistent results which reveal a substantial improvement over these values. This quantity of free hemoglobin at thaw and the increased level of extracellular potassium discourage administration of these units without postthaw processing.

Because further empirical manipulation of freezing and thawing conditions has proved unrewarding, we examined the feasibility of a simple post-thaw wash. The wash was considered mainly a dilution which, when followed by centrifugation, could permit direct administration of units. Such a wash would remove most free hemoglobin and extracellular potassium and would reduce the viscosity of the HES-red cell mixture. Since HES is not physiologically damaging on transfusion it would not be necessary to remove all of the cryoprotectant.

We noted that during post-thaw washing the Ievel of supernatant hemoglobin in the

\footnotetext{
Received September 19, 1977; accepted November 9,1977 .

1 Supported by the Medical Research Service of the Veterans Administration.
}

wash solutions increased. This was particularly noticeable when the thawed cells were washed with saline or low ionic strength solutions. The amount of hemoglobin released during washing indicated that additional cells were being damaged and/or cells damaged during the freezethaw cycle were leaking hemoglobin. This study determines the nature of red cell damage when different solutions are used to suspend thawed cells.

\section{MATERLALS AND METHODS}

Full units of whole blood (2-5 days old, collected in CPD) were centrifuged at 3000 rpm for 15 min. Following centrifugation and removal of supernatant plasma and buffy coat, the cells were washed twice with equal volumes of $0.9 \% \mathrm{NaCl}$. In experiments employing plasma as a suspension solution, the plasma was collected and stored at $4^{\circ} \mathrm{C}$ or frozen $\left(-20^{\circ} \mathrm{C}\right)$ until used.

Red cell freezing was done with $30 \mathrm{ml}$ units (final volume) frozen in liquid nitrogen and thawed in water $\left(47-49^{\circ} \mathrm{C}\right)$ as previously described (6). The starch (Lot P02303C, McGaw Corp., Glendale, California) was prepared as a $40 \%$ solution and diluted to a final concentration of $14 \%$ in the freezing mixture. If necessary, the red cells were diluted with saline prior to starch addition to adjust the hematocrit to 
TABLE 1

Post-Thaw Suspension of Red Cells Frozen in the Presence of 14\% Hydroxyethyl Stareh ${ }^{a}$

\begin{tabular}{|c|c|c|c|c|c|}
\hline & $\begin{array}{c}\text { Hematocrit } \\
(\%)\end{array}$ & $\begin{array}{l}\text { Suspension } \\
\text { time } \\
\text { (br) }\end{array}$ & $\begin{array}{c}\text { Cell } \\
\text { recuvery } \\
(\%)\end{array}$ & $\begin{array}{c}\text { Saline } \\
\text { stability } \\
(\%)\end{array}$ & $\begin{array}{c}\text { Supernatant } \\
\text { bemoglobin } \\
\text { (mg\%) }\end{array}$ \\
\hline \multicolumn{6}{|l|}{ Untreated cells } \\
\hline At thaw $(N=20)$ & 42.5 & 一 & 98.3 & 83.7 & 380 \\
\hline Post-thaw, $2 \mathrm{hr}$ & 42.5 & - & 97.3 & 83.4 & 607 \\
\hline Post-thaw, $4 \mathrm{hr}$ & 42.5 & - & 96.9 & 83.1 & 612 \\
\hline Post-thaw, $24 \mathrm{hr}$ & 42.5 & - & 96.1 & 81.1 & 687 \\
\hline \multicolumn{6}{|l|}{ Suspended cells } \\
\hline \multirow[t]{2}{*}{$14 \%$ HES } & 23 & 2 & 97.4 & 83.9 & 197 \\
\hline & 22.5 & 24 & 96.8 & 81.9 & 305 \\
\hline \multirow[t]{3}{*}{$0.9 \% \mathrm{NaCl}$} & 22.5 & 0.5 & 94.1 & 82.8 & 630 \\
\hline & 23.0 & 2.0 & 92.2 & 82.1 & 740 \\
\hline & 23.0 & 24.0 & 01.4 & 79.2 & 872 \\
\hline \multirow[t]{4}{*}{$6 \%$ Glucose (in $\mathrm{H}_{2} \mathrm{O}$ ) } & 24 & 0.5 & 96.2 & 86.1 & 393 \\
\hline & 26 & 1.0 & 95.6 & 85.5 & 429 \\
\hline & 31 & 2.0 & 94.2 & 49.5 & 605 \\
\hline & 32 & 24.0 & 94.1 & 23.5 & 718 \\
\hline \multirow[t]{3}{*}{ Plasma } & 22.5 & 0.5 & 97.1 & 82.2 & 274 \\
\hline & 22.0 & 2,0 & 96.2 & 82.9 & 323 \\
\hline & 23.0 & 24.0 & 95.1 & 80.4 & 507 \\
\hline \multirow[t]{3}{*}{ Dextrose-mannitol buffer } & 17.5 & 0.5 & 94.8 & 82.1 & 449 \\
\hline & 18.0 & 2.0 & 94.3 & 82.0 & 517 \\
\hline & 16.5 & 24.0 & 91.6 & 79.7 & 721 \\
\hline
\end{tabular}

a Final volume of freezing mixture: $30 \mathrm{ml}$. Suspending solutions were mixed with equal volumes of the thawed freexing mixture immediately following thaw and left for time indicated in table. Values shown are averages of three to four samples.

that desired in the freezing mixture. The parameters used to evaluate the cells at thaw and following suspension included cell recovery, saline stability, and supernatant hemoglobin levels (6).

Unless noted otherwise in the text, suspension of cells was done immediately following thaw by mixing equal volumes of the thawed HES-red cell mixture with the suspension solution. The suspension solutions used included saline $(0.9 \% \mathrm{NaCl})$, plasma, $6 \%$ glucose $(0.33 \mathrm{M}$ dextrose in water), and buffered dextrose-mannitol $(0.18 \mathrm{M}$ dextrose and $0.25 \mathrm{~m}$ mannitol in 0.15 м sodium phosphate, $\mathrm{pH}$ 7.3). Dextrose $(0.2 \%)$ in $0.8 \% \mathrm{NaCl}$ was substituted at times for $0.9 \% \mathrm{NaCl}$ with identical results.
Fixation and preparation of cells for electron microscopy were carried out as previously described (1).

\section{RESULTS}

Table I summarizes results obtained when red cells frozen and thawed in the presence of $14 \%$ hydroxyethyl starch (HES) are suspended in various wash solutions at room temperature. Cells left for $24 \mathrm{hr}$ (without suspension in wash solutions) reveal greater damage than is present at thaw. This is indicated as an increase in the supernatant hemoglobin to nearly $700 \mathrm{mg} \%$, a drop in the saline stability to $81 \%$, and a reduction in the cell recovery to $96 \%$. These values indicate greater post- 


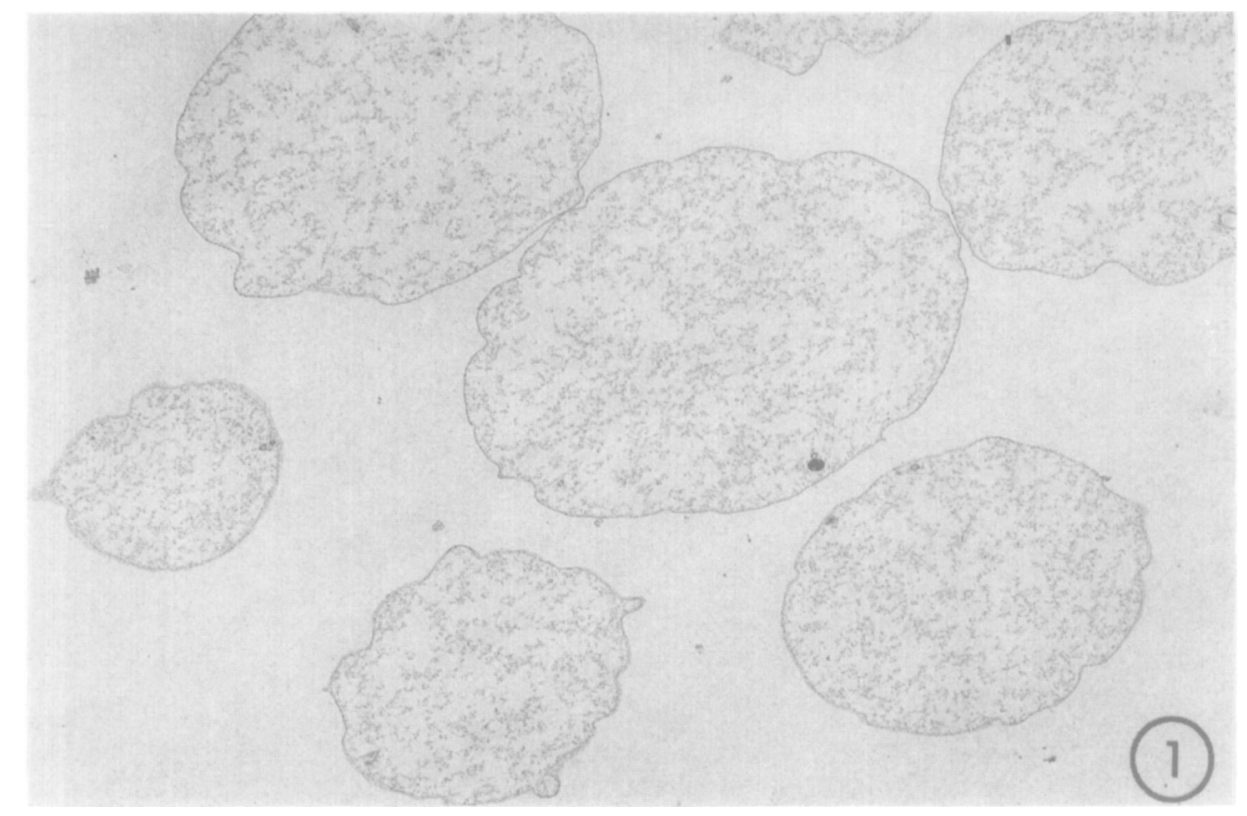

Fic. 1. Ghost-like appearance of cells following extended surpension ( $4 \mathrm{hr}$ ) in $0.9 \% \mathrm{NaCl}$ and centrifugation. Ciclls shown are present in an upper layer which comprises 12-14\% of the total cell population. $\times 8400$.

thaw damage than was previously noted when large units were maintained at $4^{\circ} \mathrm{C}$ following thaw (I).

If thawed units are diluted with equal volumes of the suspension solutions shown in the table, damage greater than that indicated above nearly always occurs. An exception is seen when cells are suspended in $14 \%$ HES which results in findings similar to cells not suspended in solutions. The supernatant hemoglobin values shown for suspended cells represent data from solutions in which the cell concentration is onehalf that of the controls (see hematocrits). The greatest damage is indicated when cells are suspended in $0.9 \% \mathrm{NaCl}(24 \mathrm{hr})$. This results in decreases in the cell recovery to $91.4 \%$ and in the saline stability to $79 \%$ and in an increase in the supernatant hemoglobin to more than four times that present at thaw. The other solutions used vary somewhat in their effect on cells but all indicate considerable damage beyond that present at thaw. The saline stability changes the least from values indicated at thaw. However, an exception is noted when
$6 \%$ glucose is used as diluent; at $24 \mathrm{hr}$ the saline stability is reduced to below $25 \%$.

Upon centrifugation of cells suspended for $4 \mathrm{hr}$ or longer, it was noted that the cells consisted of two distinct layers. Electron microscopy revealed that the top layer consisted of ghost-like cells nearly devoid of contents (Fig. 1) while the lower layer consisted of intact, although distorted, cells (Fig. 2). Hematocrits of such suspended cells indicated that the top layer (ghosts) made up 12-14\% of the cell population. Ghost cells were not observed following suspension of thawed cells in $14 \%$ HES or in cells not suspended but remaining in the thawed red cell-HES mixture. However, electron microscopic observations on cells with $14 \%$ HES present indicated a major ultrastructural change from that noted at thaw. Deposits of amorphous material appear on the surface of a portion of the cells (Fig. 3). Often a gap is noted in the cell membrane where the deposits are seen (Fig. 4).

The results with the various suspension solutions indicated that a number of thawed 


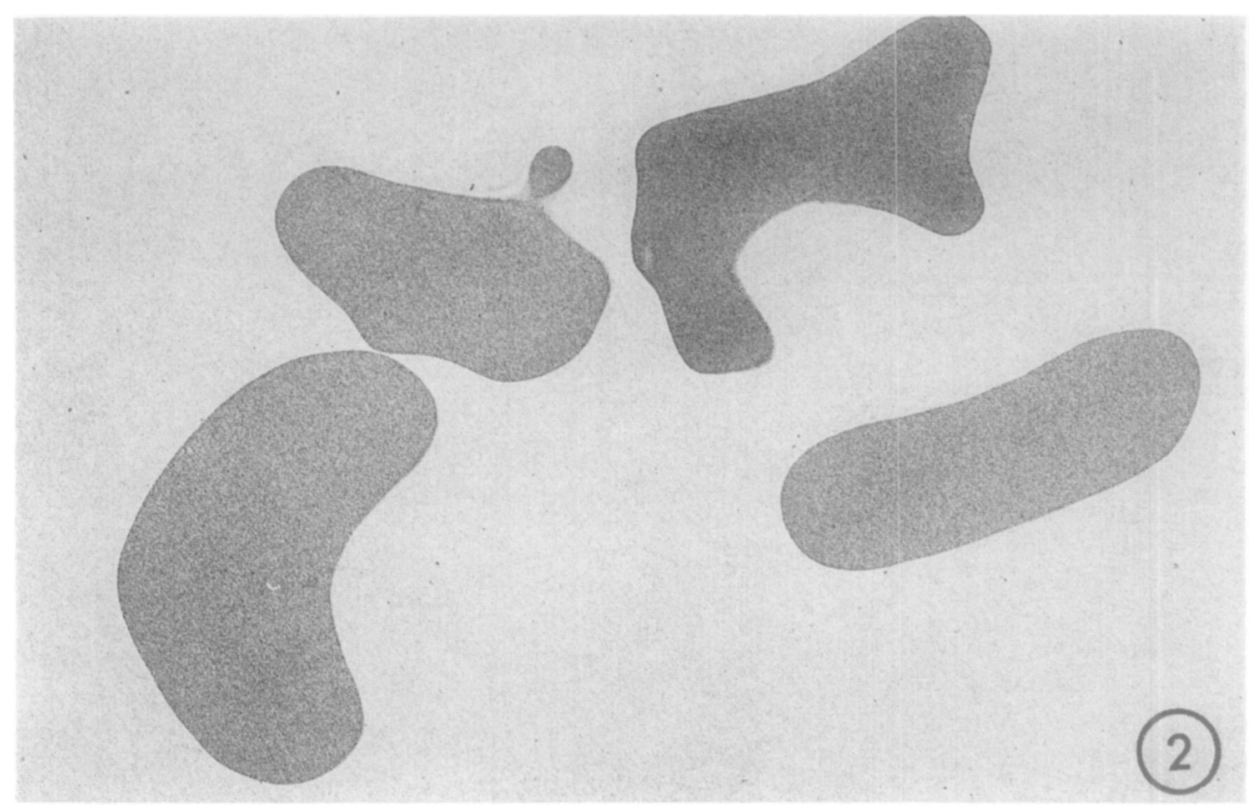

Fıc. 2. Intact red cells observed following extended suspension in $0.9 \% \mathrm{NaCl}$ and centrifugation. These cells are found among those sedimenting below cells indicated in Fig. $\mathbf{l}$. $\times 6400$.

cells lose hemoglobin following suspension. To determine the extent and relative rate of hemoglobin loss, thawed cells were suspended in different volumes of $0.9 \% \mathrm{NaCl}$ and examined for levels of supernatant hemoglobin. As shown in Fig. 5, a dilution of $1: 9$ (red cells:0.9\% $\mathrm{NaCl}$ ) results in a rapid increase in supernatant hemoglobin which reaches $17 \%$ of the total. With the above dilution, there is no increase beyond 2 hr. In contrast, a lower dilution (1:2) indicates that hemoglobin loss continues gradually beyond $2 \mathrm{hr}$ and throughout the 24-hr test period reaching a hemoglobin loss of $15 \%$.

\section{DISCUSSION}

Units of red cells frozen in the presence of $14 \%$ hydroxyethyl starch exhibit signs of additional damage when the thawed mixture is diluted. Such damage is indicated by an increase in the level of supermatant hemoglobin and reduced cell recovery which occur whether the cells are suspended in saline, plasma, or high jonic strength solutions. When suspension times are extended for several hours some of the cells lose nearly all their contents. The various suspension solutions tested appear similar although some may delay the time when damage occurs. This is the case with $6 \%$ glucose which shows evidence of damage only after $2 \mathrm{hr}$ (Table 1). However, when $14 \%$ hydroxyethyl starch is used to suspend thawed cells, the findings are similar to those of untreated thawed cells.

Some of the thawed cells exhibit gaps in their membranes (1). Following a period of storage in the thawed mixture which contains $14 \%$ HES, deposits of amorphous material are visible on the surface of some cells. Since the membrane is often missing where the deposits occur, it is probable that cell contents escape through the openings visible in the cell membrane. Since the majority of the protein in the red cell is hemoglobin, this material would contain considerable hemoglobin. However, at the time when these deposits are observed on the surface of some cells, the level of supernatant hemoglobin and the cell re- 


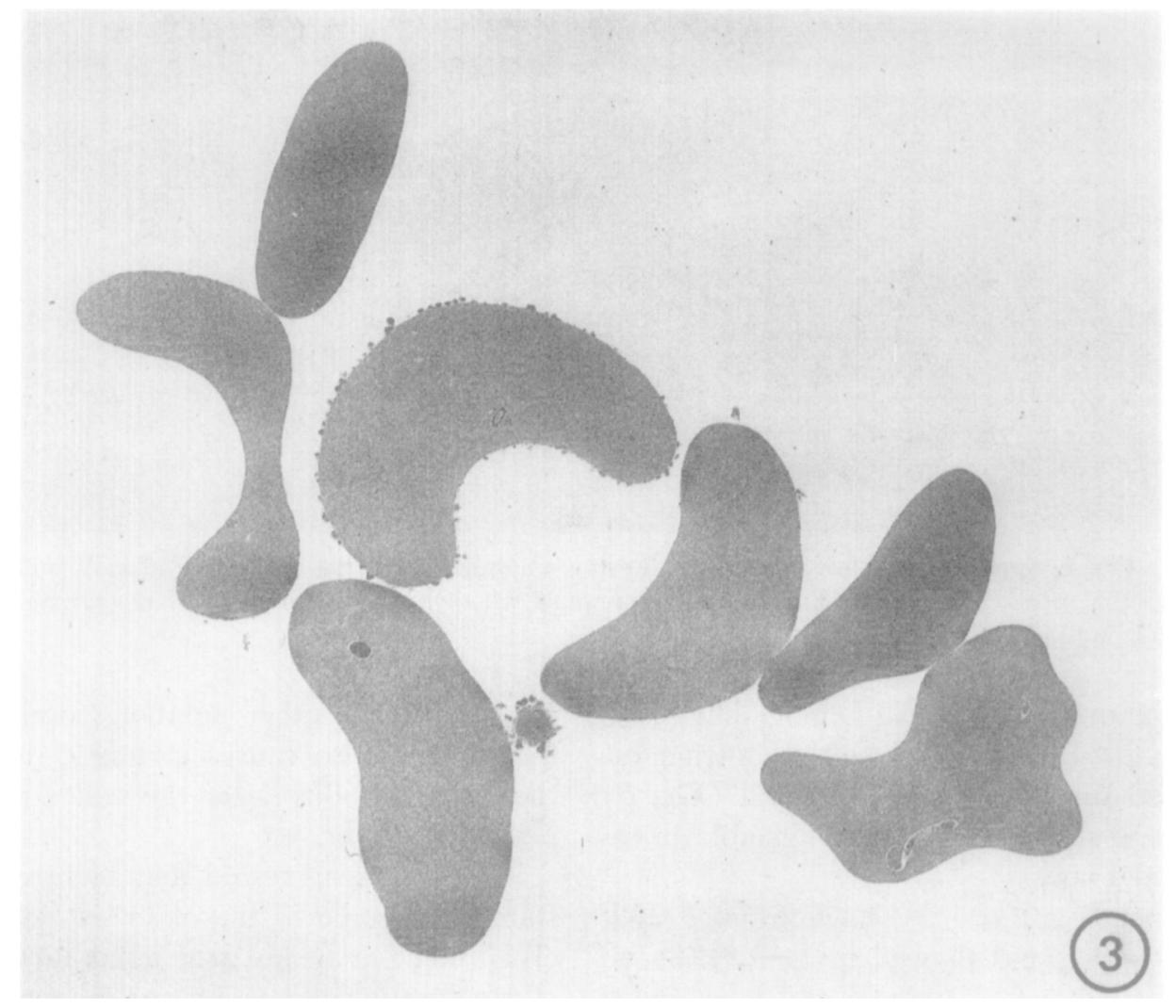

FIG, 3. Appearance of red cells following suspension $(4 \mathrm{hr})$ in $14 \% \mathrm{HES}$. Deposits of amorphous material may be seen surrounding one cell. $\times 7300$.

covery value have changed only slightly as compared with values obtained at thaw. Apparently the cell matrix and hemoglobin are adherent to the surface of these cells and do not readily enter the external solution ( $14 \%$ HES).

These deposits are not observed in cells suspended in solutions without HES. However, since suspension results in increased levels of supernatant hemoglobin, it seems apparent that the material observed as a deposit in thawed cells (left standing) bccomes dispersed in the external solution of suspended cells. Suspension solutions thus appear to provide an environment whereby the cellular contents which leave damaged cells can diffuse from the cell surface. It is likely that only those cells which become "ghosts" are damaged. When thawed cells are diluted 10 -fold with $0.9 \%$
$\mathrm{NaCl}$, there is no increase in the level of supernatant hemoglobin after $2 \mathrm{hr}$ (Fig. 5). These findings suggest that the cell recovery test is probably not an accurate indicator of cell damage following a freezethaw cycle with $14 \%$ HES as a cryopreservative. A certain number of the thawed cells are damaged but the extent of this damage is not apparent using this test in the presence of $14 \%$ HES. Alternatively, the saline stability test is a more realistic asscssment of ccll damage in the presence of the starch. This test, performed by diluting (40-fold) a portion of thawed cells in $0.9 \% \mathrm{NaCl}$, generally indicates about 10 $12 \%$ more damage than the cell recovery test at thaw. Yel, following standing of the thawed cells or their suspension in a variety of solutions the saline stability changes only slightly from the values obtained at thaw. 


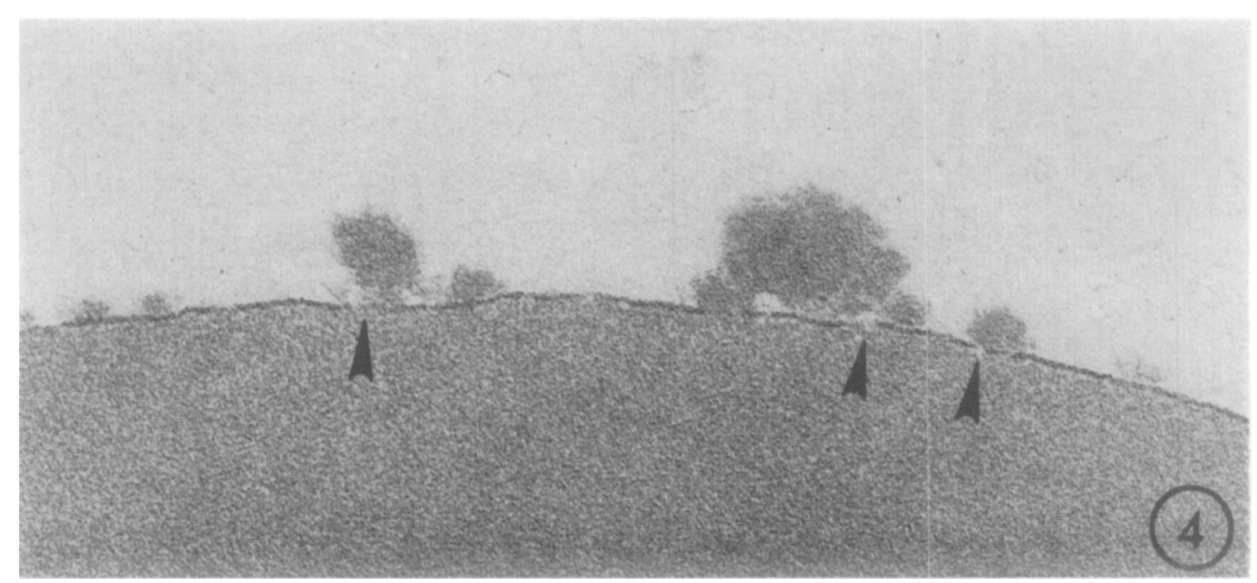

Fic. 4. Appearance of cell membrane showing amorphous material on surface of cell similar to that present in Fig. 3. Arrows indicate regions where a portion of the cell membrane is missing. $\times 69,850$.

Furthermore, the loss of hemoglobin (17\% of total) from thawed cells following extended suspension in $0.9 \% \mathrm{NaCl}$ (Fig. 5 ) is nearly identical to those unstable in saline at thaw.

Lionetti et al. (2) have implied that cells frozen and thawed in $14 \%$ HES and suspended in $6 \%$ glucose and centrifuged may be used for transfusion. Our findings indicate that this solution will not prevent cells from undergoing the damage noted.
In contrast to other solutions examined, $6 \%$ glucose also causes a drastic drop in the saline stability after the cells are suspended for $2 \mathrm{hr}$.

It has been suggested that hydroxyethyl starch and some of the other extracellular cryoprotective agents may act as stabilizers of membrane components. As indicated by Meryman, such agents do stabilize proteins under various adverse conditions (3). Such a role for hydroxyethyl starch during the

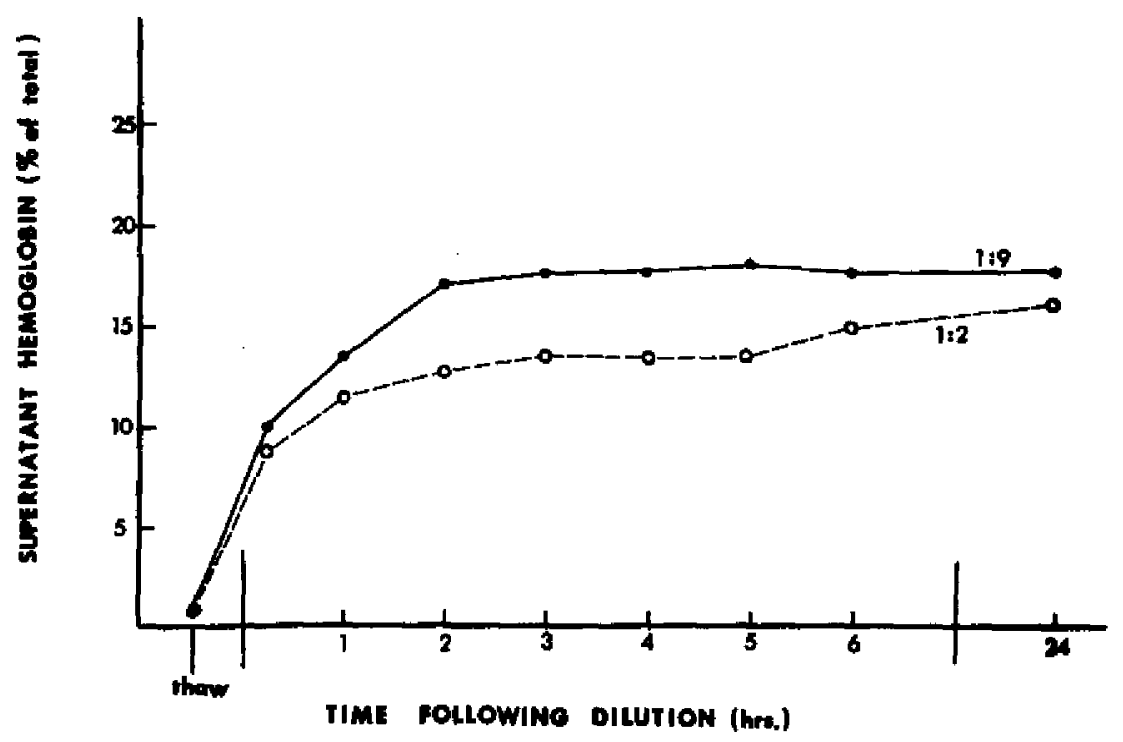

Fic. 5. Percent hemoglobin lost from cells diluted 3-fold (1:2) and 10-fold (1:9) with $0.9 \% \mathrm{NaCl}$. Samples were diluted at thaw and first reading taken at $15 \mathrm{~min}$ post-thaw. 
freeze-thaw cycle probably exists, however, it appears that following thaw, this agent has little effect on preventing or reversing the damage noted here. The presence of $14 \%$ HES in the thawed mixture probably does not prevent the cellular contents from leaving the cell but instead appears to retard them from readily diffusing from the membrane surface into the external solution. This may be caused by the high viscosity of the starch solution and may be similar to the effect of suspending hemoglobin concentrates in solutions of polyvinylpyrrolidone (PVP) (7). This also raises the question of whether the reduced hemolysis observed when thawed red cells are suspended in solutions containing extracellular agents is caused mainly by the viscosity of the solution $(4,5)$. Once the viscosity is reduced by suspension in various solutions, the barrier to diffusion is lessened and hemoglobin can enter the external solution.

\section{SUMMARY}

Post-thaw suspension of red cells cryopreserved with hydroxyethyl starch (HES) gives rise to an increase in the quantity of supernatant hemoglobin and a reduction in cell recovery. This occurs regardless of the suspension media used but may be delayed by some solutions. Extended suspension with most solutions results in loss of intracellular contents from a number of cells. The resulting ghosts account for $12-14 \%$ of the total cell population. In the presence of $14 \% \mathrm{HES}$, deposits on the surface of damaged cells indicate that cellular contents are adherent to the cell membrane and therefore do not contribute to the free hemoglobin in the external solution. The result is a misleading high cell recovery value and suggests that this test does not accurately describe true cell damage in the presence of HES. Since the saline stability of suspended cells changes very little from that prior to suspension (at thaw), its value is a more accurate assessment of cell damage.

\section{REFERENCES}

1. Allen, E. D., Weatherbee, L., Spencer, H. H., Lindenauer, S. M., and Permoad, P. A. Large unit red cell cryopreservation with hydroxy" ethyl starch. Cryobiology 13, 500-506 (1976).

2. Lionetti, F. J., Hunt, S. M., and Lin, P, S. Improved method for the cryopreservation of human red cells in liquid nitrogen with hydroxyethyl starch. Cryobiology 13, 489-500 (1976).

3. Meryman, H. T. Freezing injury and its prevention in living cells. Ann. Rev. Biophys. Bioengin. 3, 341-363 (1974).

4. Meryman, H. T., and Hornblower, M. Changes in red cells following rapid freezing with extracellular cryoprotective agents. Cryobiology 8, 262-267 (1972).

5. Pribor, D. B. PVP contrasted with dextran and multifactor theory of cryopreservation. Cryobiology 11, 60-72 (1974).

6. Weatherbee, L., Allen, E. D., Spencer, H. H., Lindenauer, S. M., and Permoad, P. A. The effect of plasma on hydroxyethyl starchpreserved red cells. Cryobiology 12, 119-122 (1975).

7. Williams, R. J. A proposed mechanism for PVP cryoprotection. Cryobiology 13, 653a (1976). 